の品 る。郎立 し とと事の 5 㤎司と第の

に、

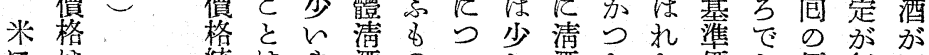

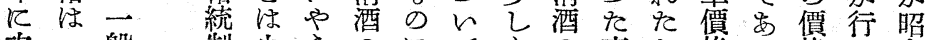

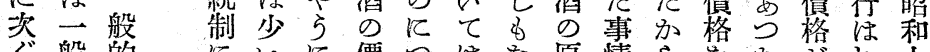

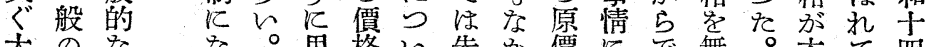

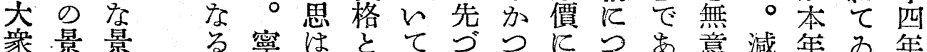

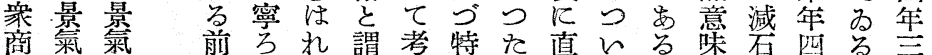

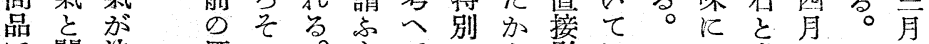

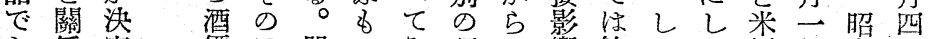
ま係定 るな的 加な 限䯩焦 奮低角

需 号な

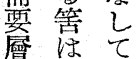

な

景

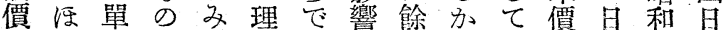
決分純は方由变の程しし引に十の 定のに昔必召方趣な正改四價

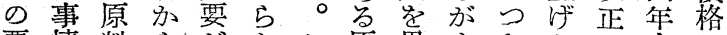

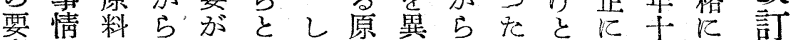
素江寧原要見吕料に十七云な月釗の

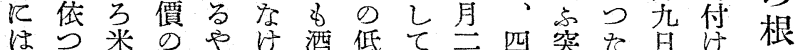

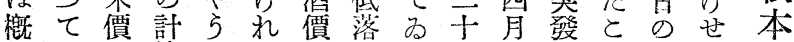

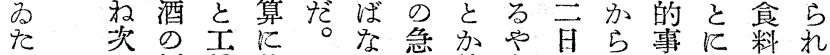
与激勞方浬項科机

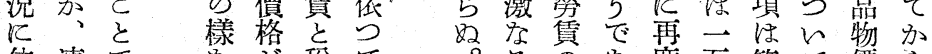
依清でなが稅て。方の亦度答て價ら

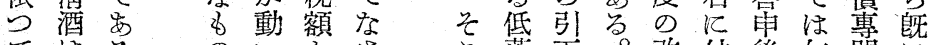

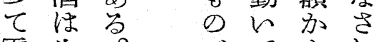
需生。加て 5 れ

夏 活勿

出さ 方势

が必論

尓放き た䧵堛

る 品 5 た

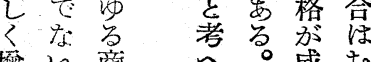

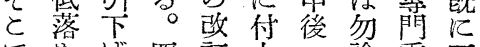
で学㑑四訂十一論委三 先餘と月五々誰員问 づ儀かかな圓月し會に 酒な云 5 さ

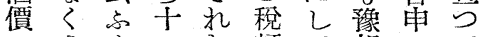
のさや二㱛額て想にて 壇々商

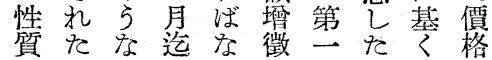

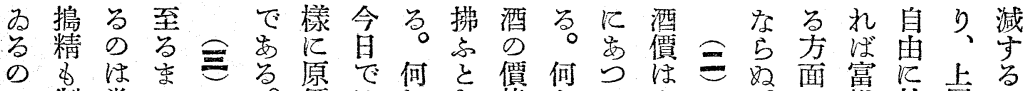

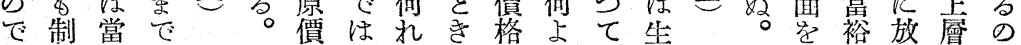

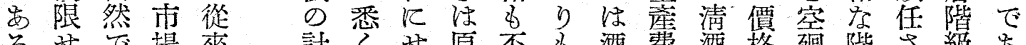

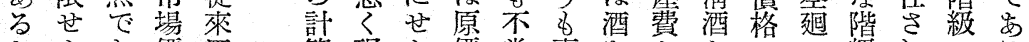
只 5 要價 酒 与 犯り、格價 算現よ價當員艺と无のつ級れのる

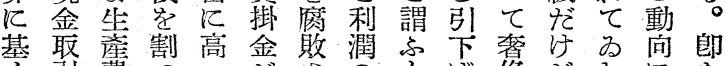
部 宣區一

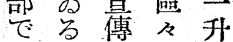
唱上費でー 气汇高買 5 㯰D为

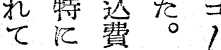
本苦酒 る 年極 米の 队息安 5 原乙體 0 亿料高 9 名 原米々高 5 價自つ低五 の體

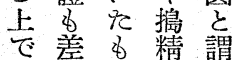

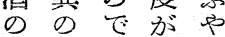
銘な 直 5 唡 25 接な 依当な價高 先今格な て 白影字 厓つ算 の

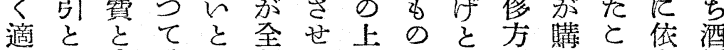

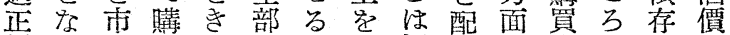

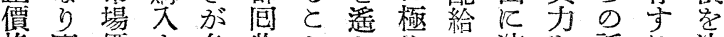

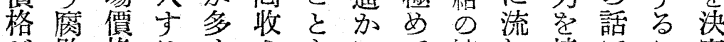
召敗格るく过にて統れ持厄て定

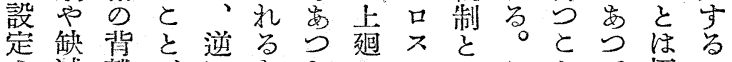

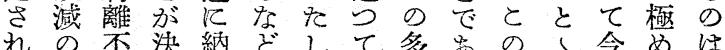
机の不決納 ぞして多要の小令めは

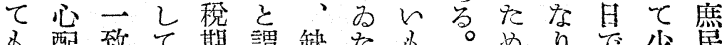

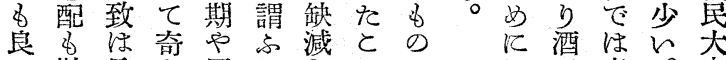
々尠見ら酒となとで 時 几逃し米と它を

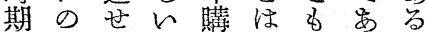

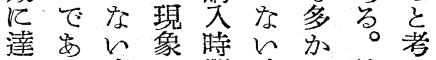

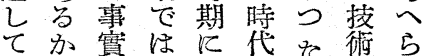
てか賽な代な仼て術ら る、古方至にた

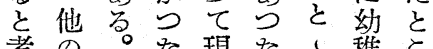
考の。た現を子稚と 黄異必专に 敵との金加思なる に酒的大 皇 宓偏柴 要在 が皆 な与違と落 手方尔光 段莲來乞謂 三学名壮 万酒。兄 探密清乍当

解 說

中

村

清 5 必酒 5 所 和要驾價以

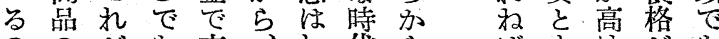
ばすけがあ

英 


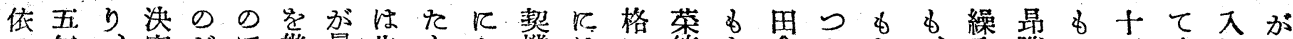

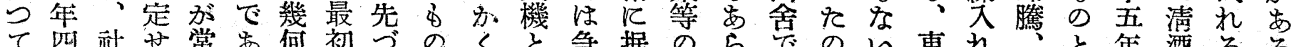

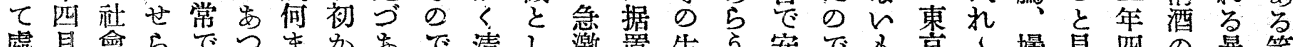

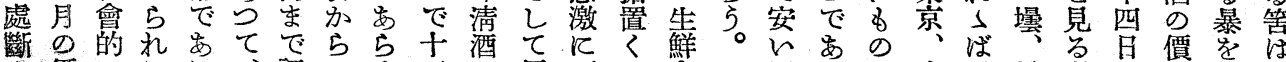

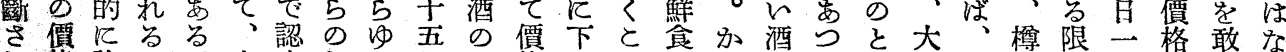
れ格許とが自容放る年夕格がと料くにて思服牛等り日をて々

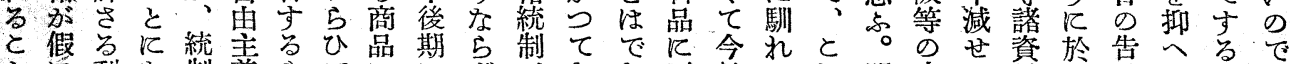

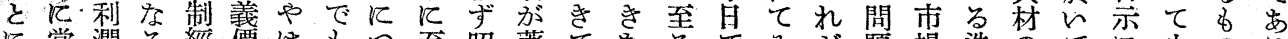

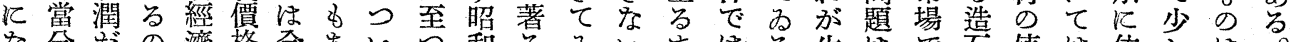
な分忙の濟格全あんつ和るるん安はる生はで石值は依乙は。 る据けで機機くつてて十しるので食金とはに上なるる市更

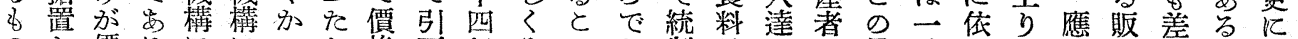

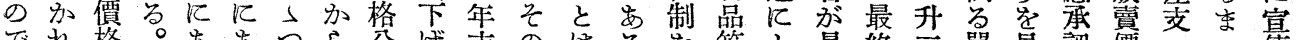

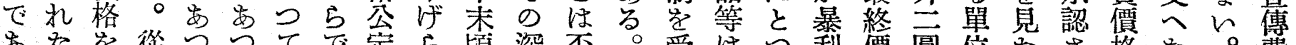

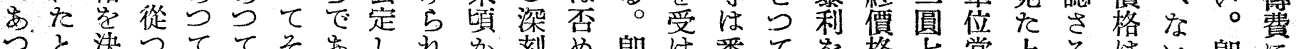

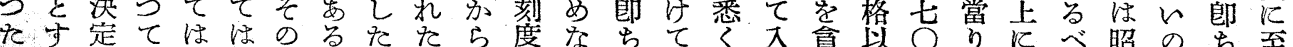

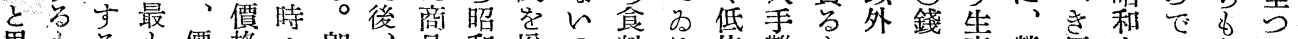

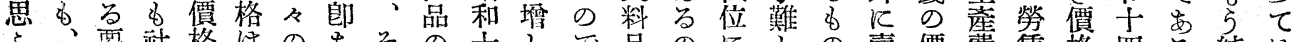

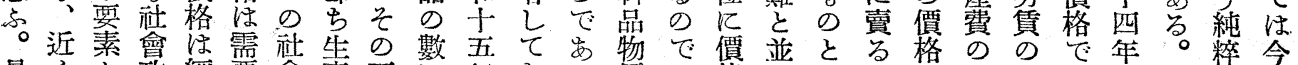

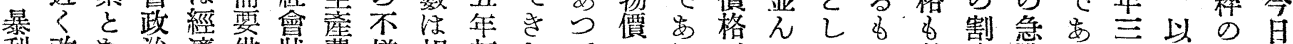

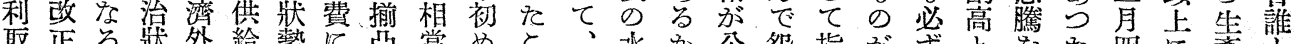

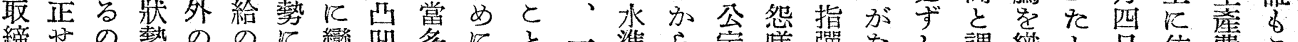

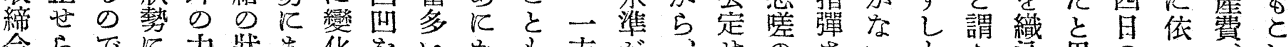

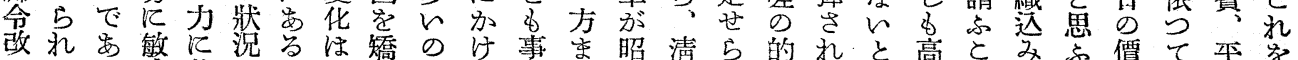

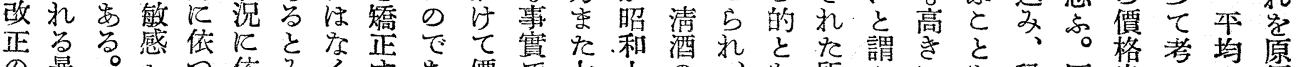

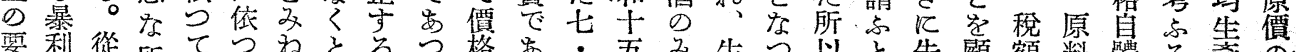

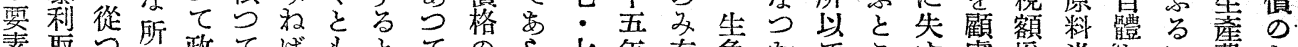

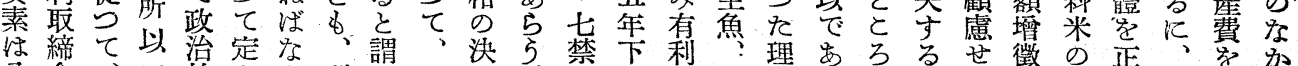

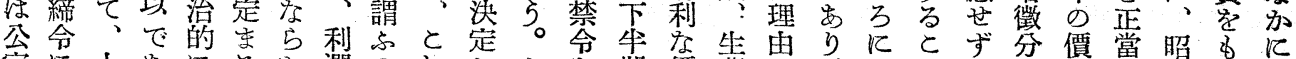

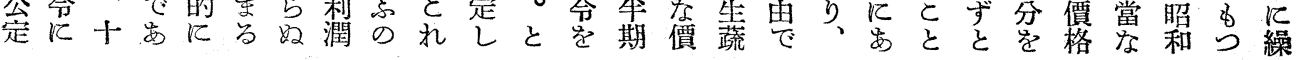

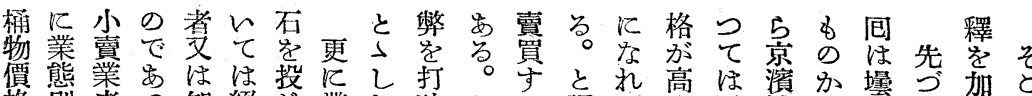

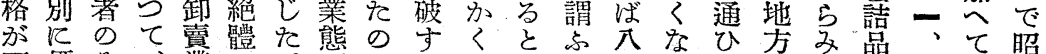

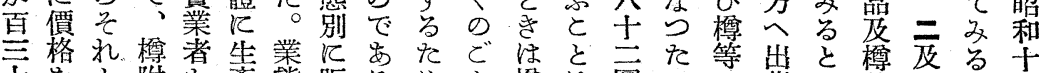

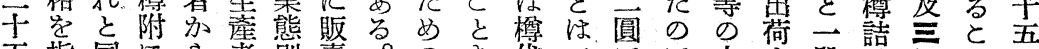

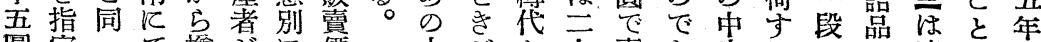

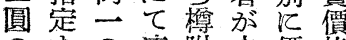
等の清附之價格 とる價酒のに格を

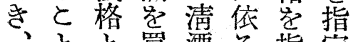
と買酒方指是 小謂悉苍定守 賣決空必買きする 才ᄂ

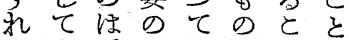
壮生安なきでとに

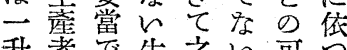

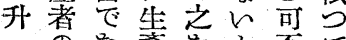
一のな㕍を否て 圓小的者量考配 七賣の架賣へ別給

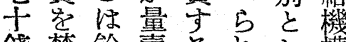
錢禁狳賣方热各構

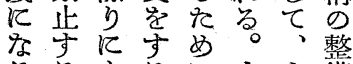
るるるる化整 の明加價賣賣間 での瞭ら格の量題

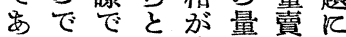

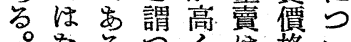

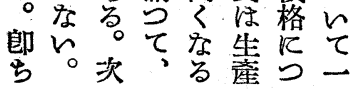

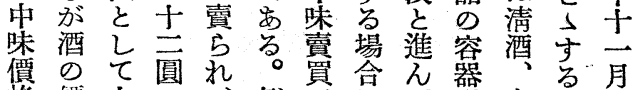

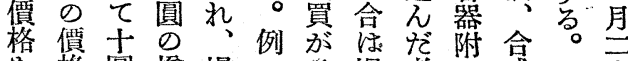

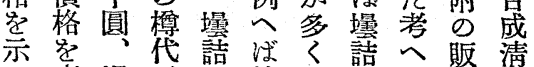

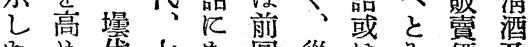

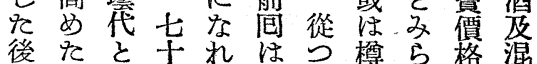

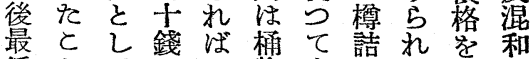

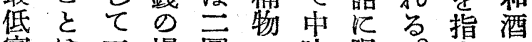

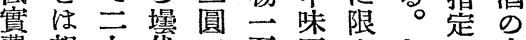

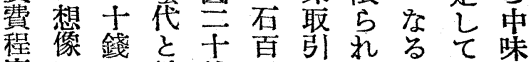

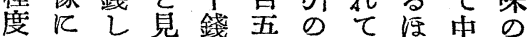
の餘吕 5 で行 る゙味販 容る引狆賣圆度る灘飞賣

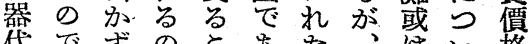

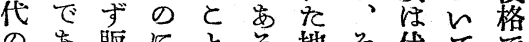

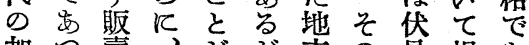

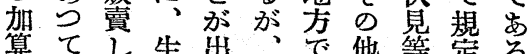

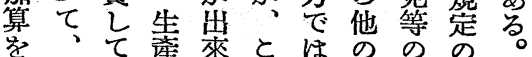
認先る者告法地主なと

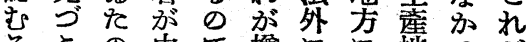
るとの中て樽汇地势 とので昧ま榼價ま加れ前
㔀总偠

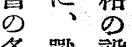

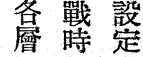
ににせ 漫 於 5 潤永热

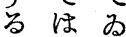
ᄃ何 子人 \& $\rightarrow \& 0$ な 利飞 tc

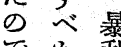
商條少省犁 省說总ず筧 謂 鐵苚 則 ᄂ 個 5 人 の 謂 幸宫 望江

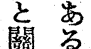
㐿。 珤要 


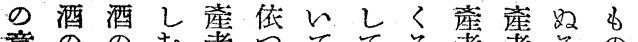

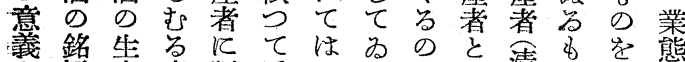

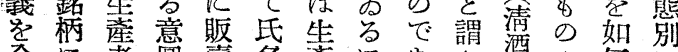

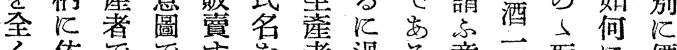
く依でです学者過吕意般取に偠

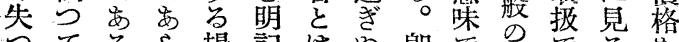

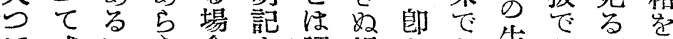

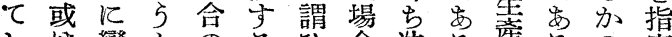

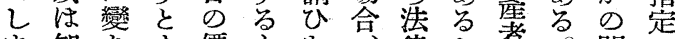

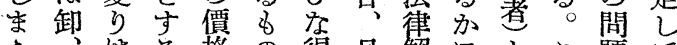

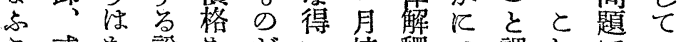

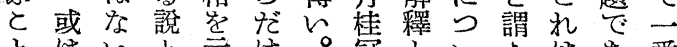
とはと示け。冠とい岕番 に小。出にして意告す䦓

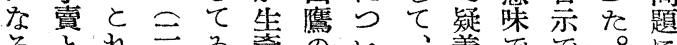

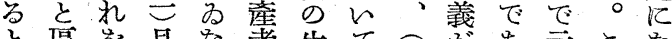
と區艺月な者生てこ出示とな

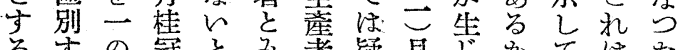

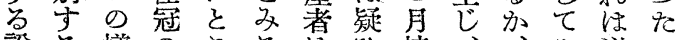
說る樣のとるはひ桂、、る逆の

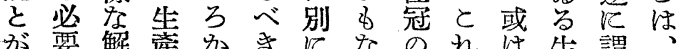

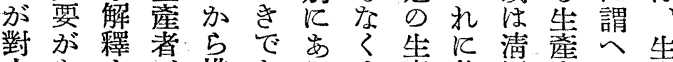

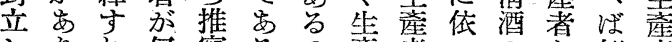

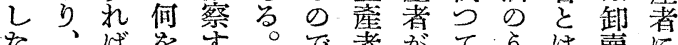

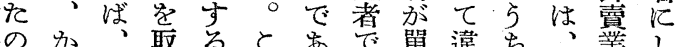

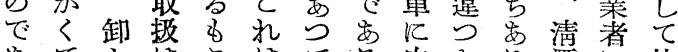

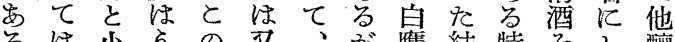

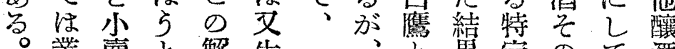

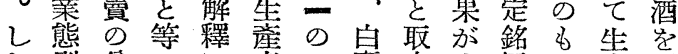

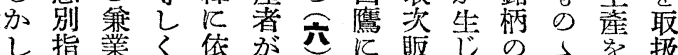

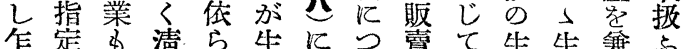

です業的土地る配價典ま步积

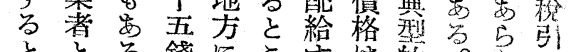

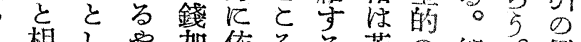

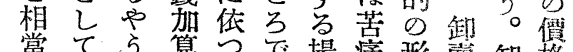

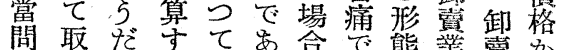

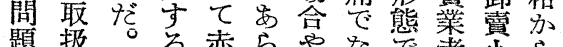

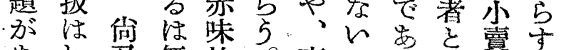
焉れ無故。值で告箫れ

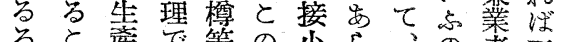

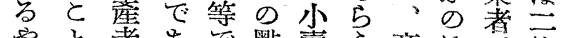

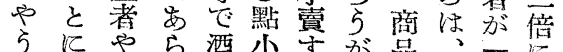

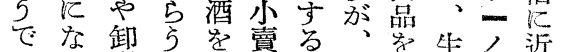

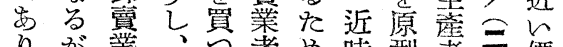
咅染業、店者め時型者三價 就、者府飞灭にの方の格

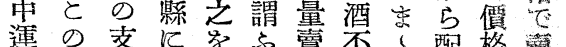
儥點店依尔の寻足取給飞格

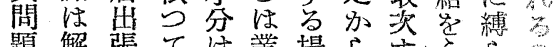
題解唇て が釋所はす態合樽方けれで

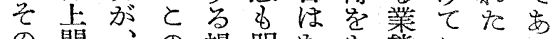
の閏、の場明な要態とのす

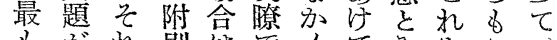

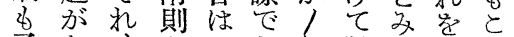

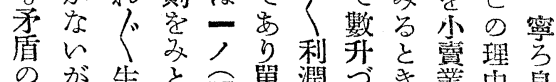

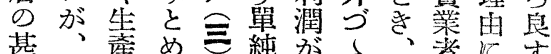

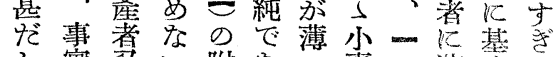
乙實文々附焉賣, 流々

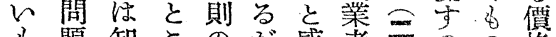

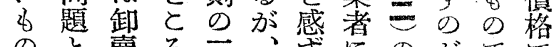

の蒷は壮件かは惡きのう量つ或

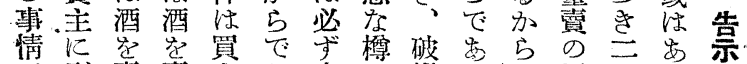

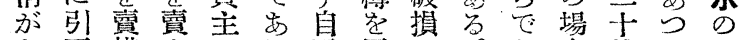

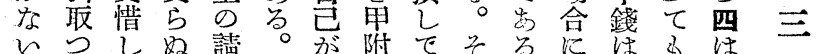
限で 己

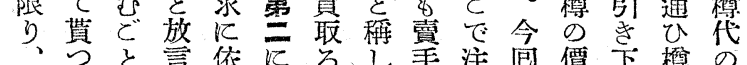

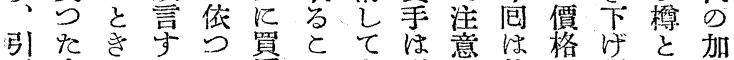

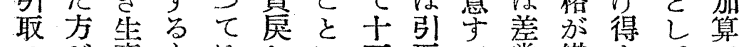

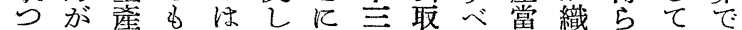

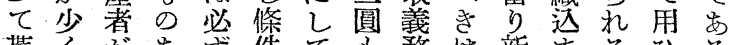

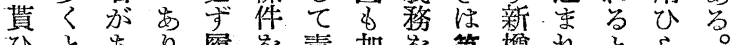

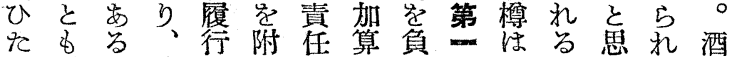

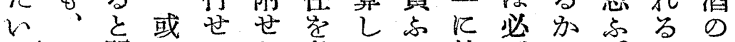
と三聞被な負て可故势

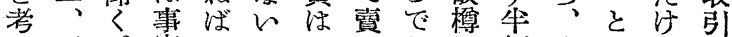
へ三。實なとしる岁は額といに名 る圓買上らきむと省故でれふなら

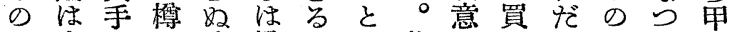

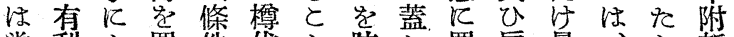

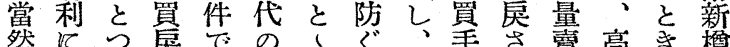

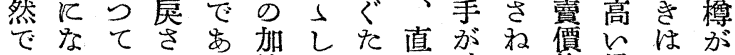

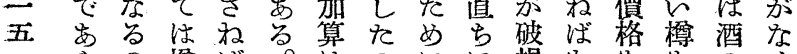

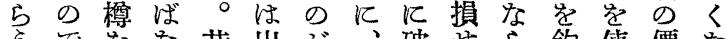

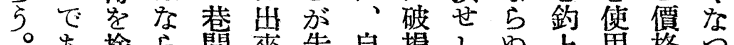

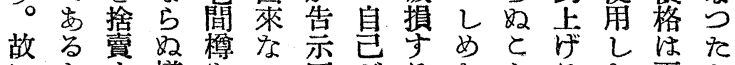

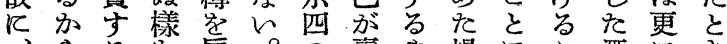
ら、る学厣。の蕒や場にと酒にき

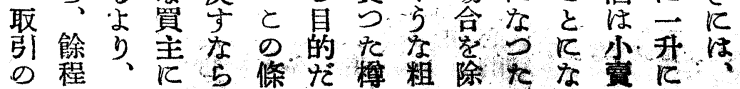

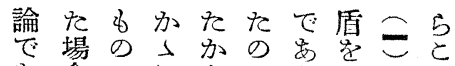

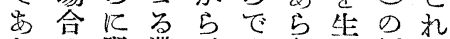
り,队限業、㐫 5 じ偠は

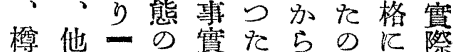
詰眩の\&閔が、で依閣 品酒三の題: - 安 5 題 又と三骂事の方它

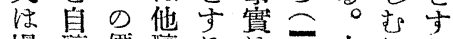

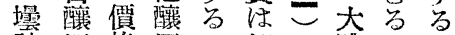
詰酒格酒と卸の體とと 品と㳖取賣下段の此他 取混 5 々不者の如と酒 次合して能に價きの导

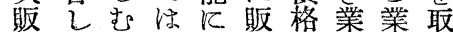
賣たる、陷賣で者者扱

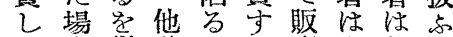
て 合得釀と学賣少却生

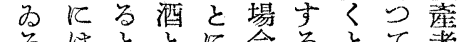
るほとと活るとて者 場一ししな㤎方買 合のたてつ石き値と

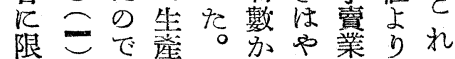

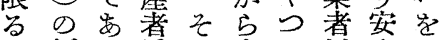

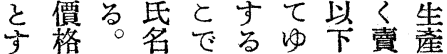
る但を解とけに署 の依乙明䆁遥る睖衫と

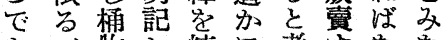
恋物し統に考すなな 当学て一多へ尔らし

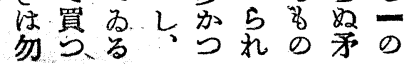




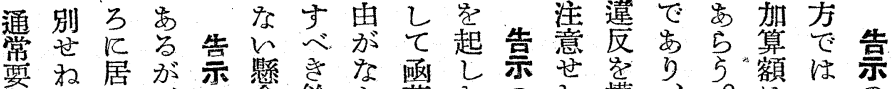

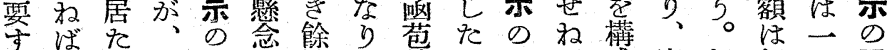
心店場今七茫地た等と六法成容無新升五

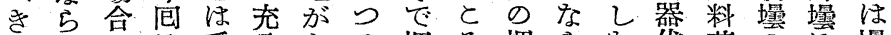

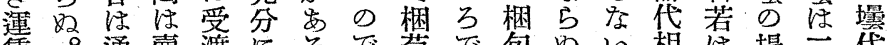

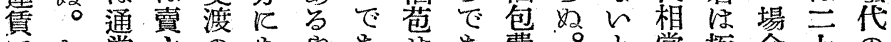

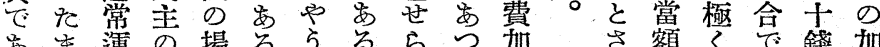

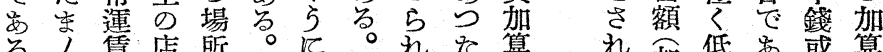

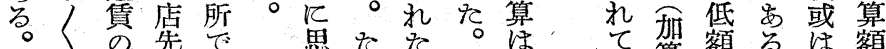

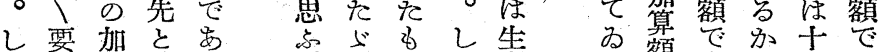
加算改当 乙 がめ 乍費許 5 從 与用只れ來 小でれたは 賟点号徒 業なとと從 䇎 乼、と百 一通な賣最 升常当主寄 理使。㤎鍳 要角通買 叉 渻常主

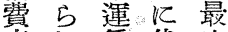
者机儥代寄 点情巽 と尰噻て買渡

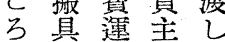
にに任のた 屆依学と品

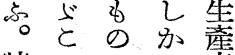

特の品乙者

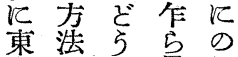
京范最多 は明終認 神䭪瞭渻め 奈詰等費

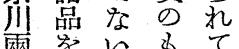

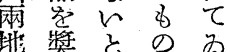

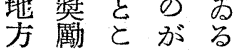
以守 3 它

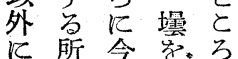
は以国買吕 詰決て山 品的定的

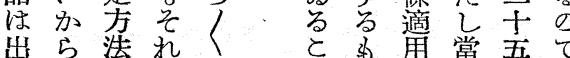

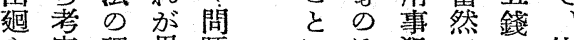
与究理果題

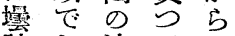
方額容 5 五 艻学故錢方 5 足䭪 9 が 䭪合收角算れ

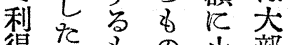
得劣 当相加嘡 と額檟算 る 塌 在等低や》 禁妾統減 5 ン ぜ拂制守它ク

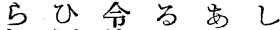
れ国第应方て て收公け。る るす條だ二る

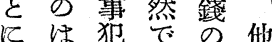
では年の額

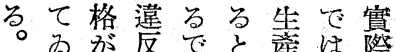
るが反染鲁者な際

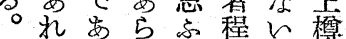

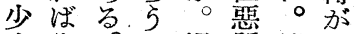
々 そ。㬡質筆返 との新思文者つ

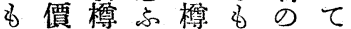
本格以。たの經來 荷第儲は驗て 造との三けなをる 它归はるく綜な なる取買と、合々 于涯值扊と此守生

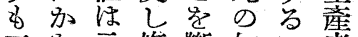
圆な示條䜝如㳊者

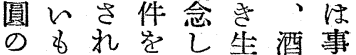
加のて附た產の實 算とふ守䁱者中上 は思なるにの味違 でふ心\&は要で反 等分酒求な な本ら額のがして 荷停员取酒に。

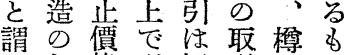
ふ加格引極引やす と算取めを䭪と

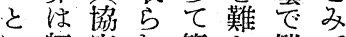
反既定初簡分儲て なに或ば單しけ㱠 る廢梳と明くええ

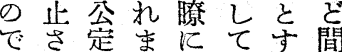
む゙れ定まにてすす間
のは全 料

七本罭方夎 中當な謂度 味り ふ 他 偠车需ぎの や.分磨方烈 經稅がのな 營額行 で 費殘き㐫酒 ○亘包精 運只り、含 貨全渻其飲 利㤎費の 料 潤 喂 8 販飞 艾函逐路比 見の年的す 万價增都れ と格加市ば ととしに に抑つ重儿 なへ小點 万て焉年、 の良つ指 下的分分 弯。少 る 從 麥低 吅酒 5てのる一 價 原 が種 稅格 價、の 額 $の$ 最㬐 西分構近好

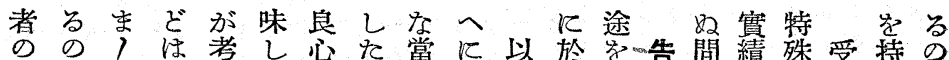

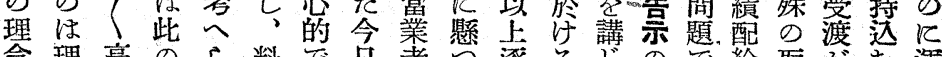

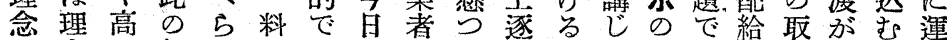

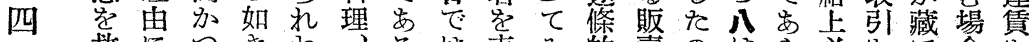

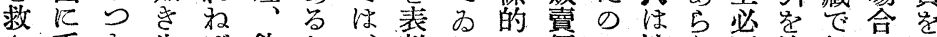

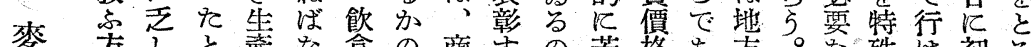

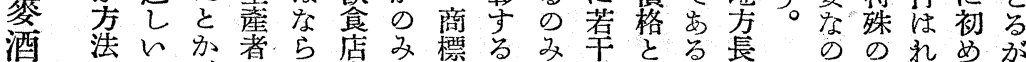
のはの、居方でに何ての出。宫で價中て如

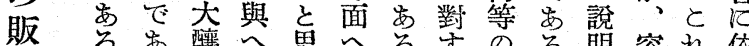

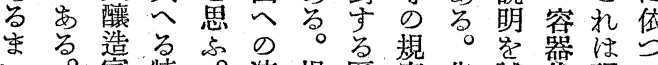

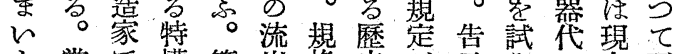
と賞で權筆出格史方示多の在更

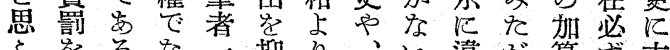

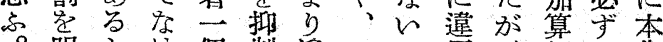
明とけ個制遥のの反額し告

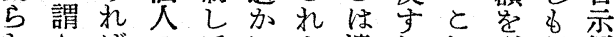
からばのてにん遺れれ洦理價 にやな考 ま上な憾证卡想格 す $55 へ$ る

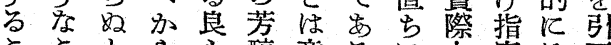

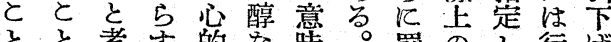

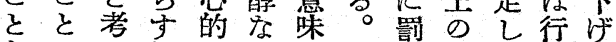

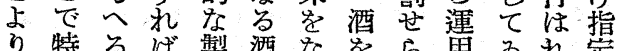
引特る㳊製酒な学ら角るれ琴 は殊。一造を造れは当てす 殹銘單の家造な方結となる

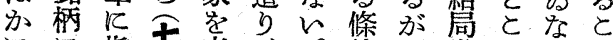
に涽も表、。件、當乃衣 現指定の彰凓閒が現業ががの 在定昌特尔題全在者多、出

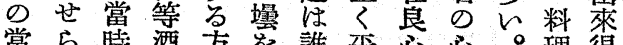

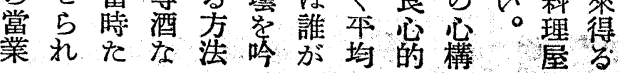

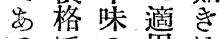
つての用 て設價 加許 定格 ま岂

配于がるれ 給 る 基とな 組 の準 久 織唯とて・当 が不な良の 確合つ反て 立理てであ 乙のみあ己 た樣亏 5 て 琵思亩 5 例 再机告、゙六 に示、料 考。管 慮とは: 店 就桶等 水泩四 ばじと 斗 な酒謂樽 思司。例 


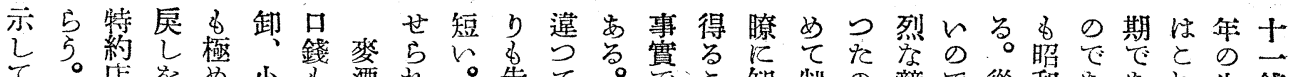

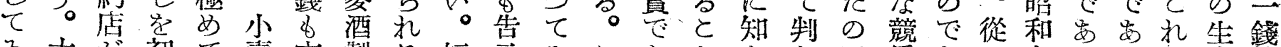

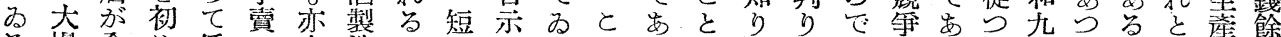

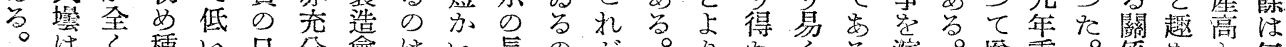

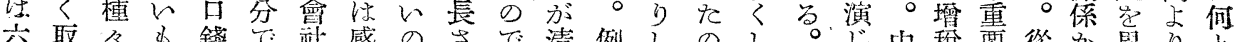

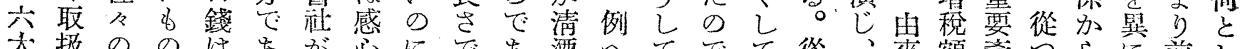

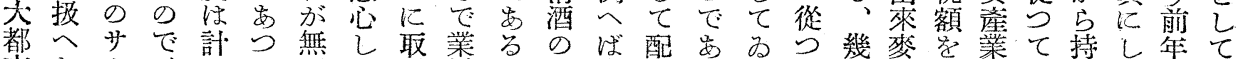

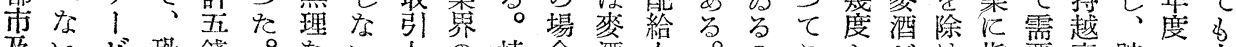

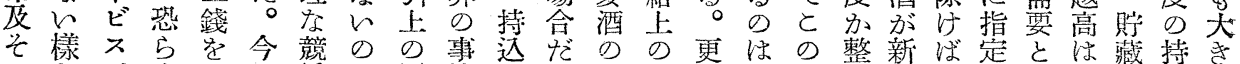

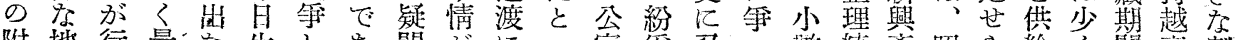

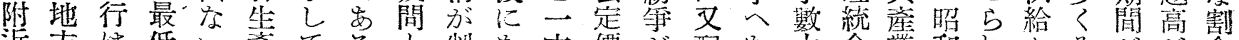

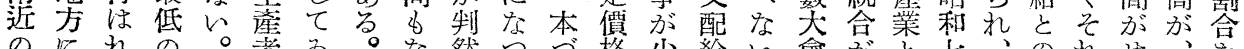

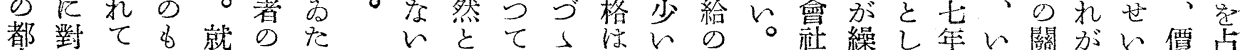

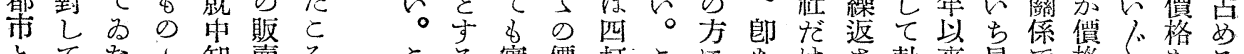

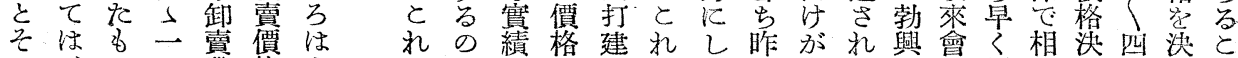
の、のつ業格小 他多名渚蕒 の少、岕の既の 地 今 5 口 方割间 5 錢四錢 と戻は。率十は 它裸從泞錢十 販 范來他离錢 賣 ᄂ 價零 僳它格酒商充り 、 を方な取と台卸

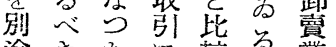

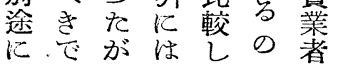
がでだにには年存た期社價場定、定と

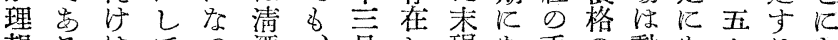
想るはてつ酒、月し現あ手の動焉万万な

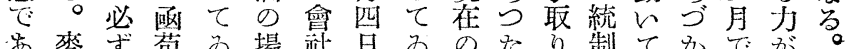

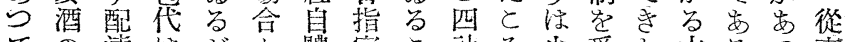

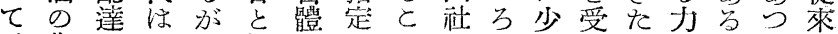

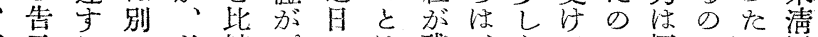

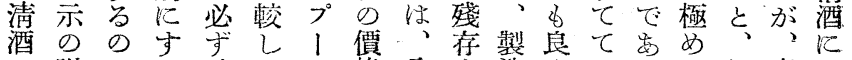

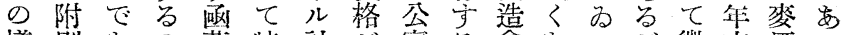

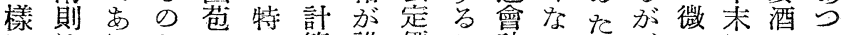

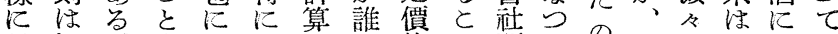

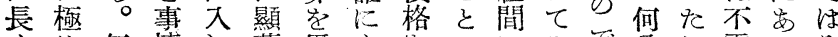

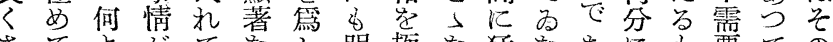

指せ割てに否

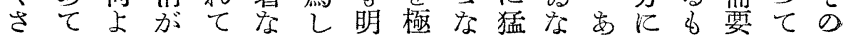

外格あるめののあやらさ要飲るめて來

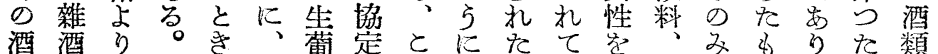

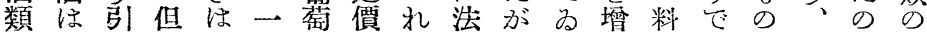

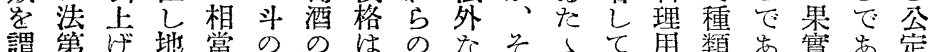

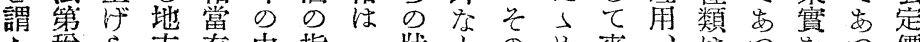

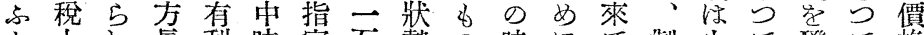

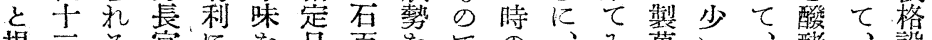

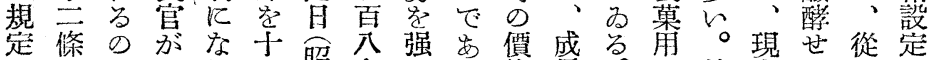

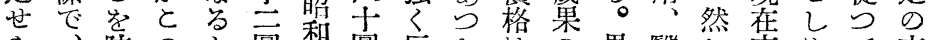

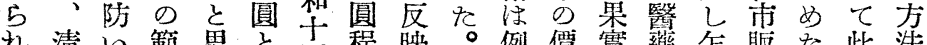

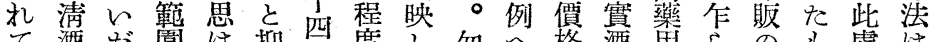

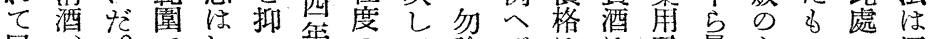
居、。でれ势のて論ばはは最るので酒

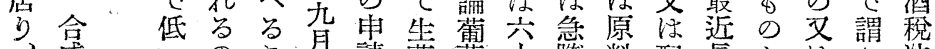

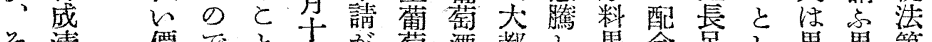

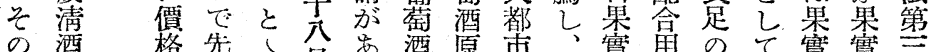

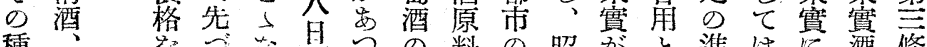
種

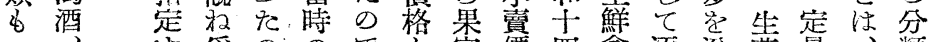

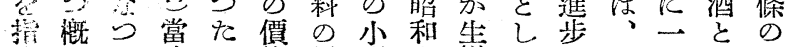

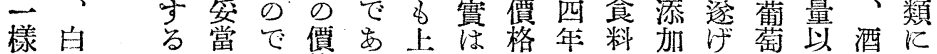

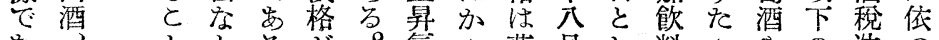

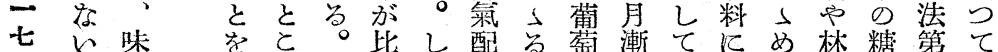

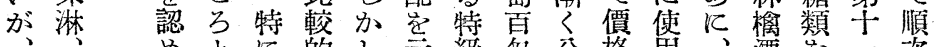

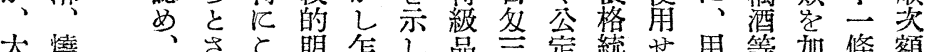

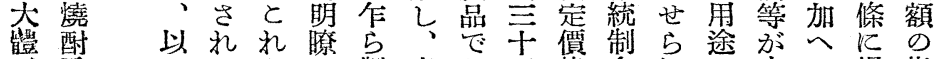

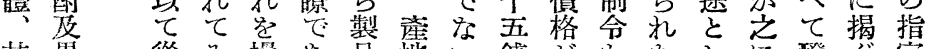

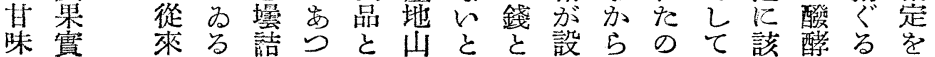

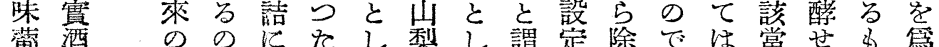

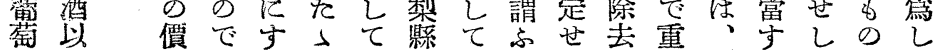

乙加料や指

号理 ど是麥

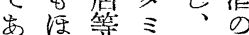
五 らででン注告 与と賣ビ吕示

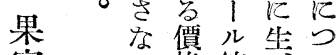
實年格等

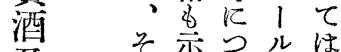

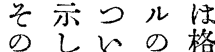
案て偠別 与专格述 來当從飞心 客架來指方 供と格しき 等机荎て宊 万は娄的 口酒及多 でよとのな क 5 め的 分口額要四 与錢点 と指。詓

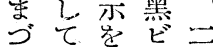
此保合 む少てル䇠 艺会や度 得架等不咅 尔何酒多咅 との場卜窝 


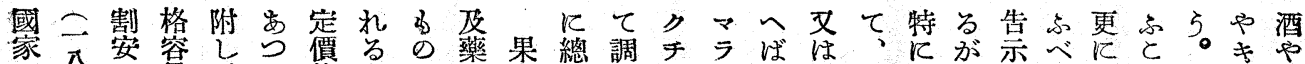

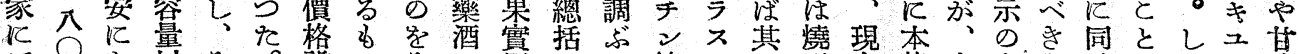

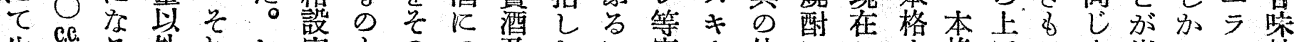

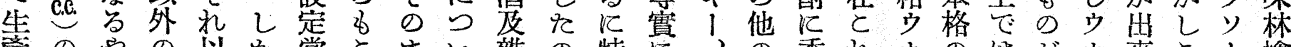

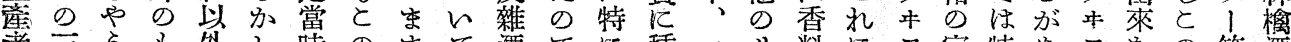

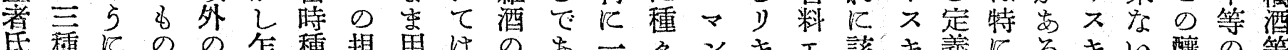

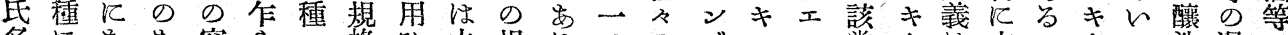

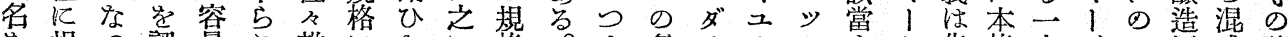

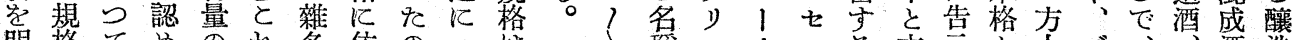
明格てめのれ多依のエは

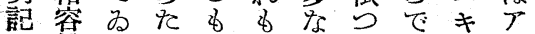
せ量るとの市容てあ市不

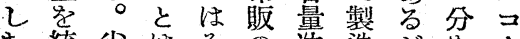

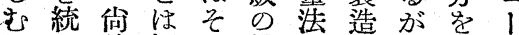
る一將經机最 9 乙今视儿

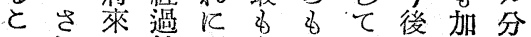

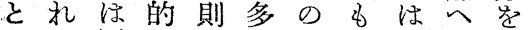

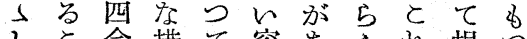

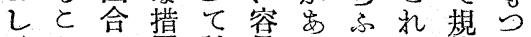

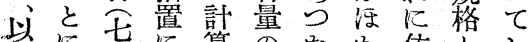

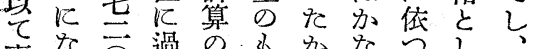
責な

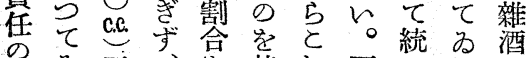

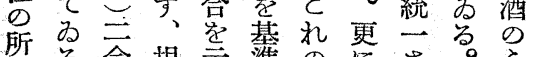
在。合替示準口尔。弓

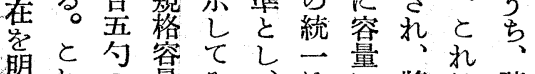

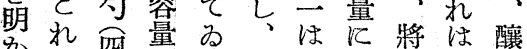

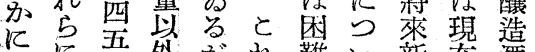
几兄外吕机難 $\tau \supset$ c.e. 0 亿な⿻儿口市

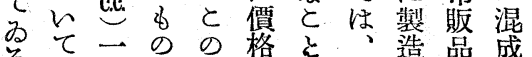

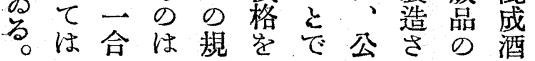

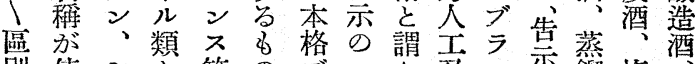

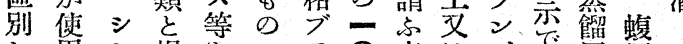

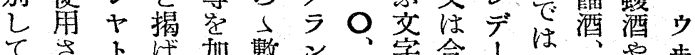

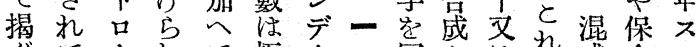

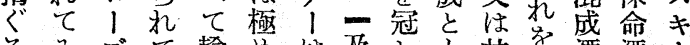

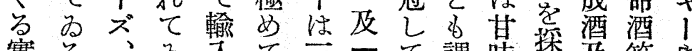

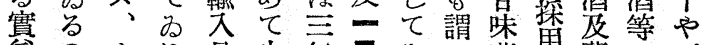

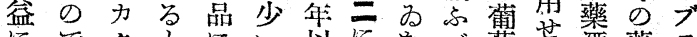

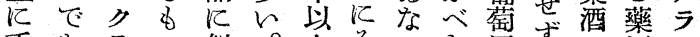

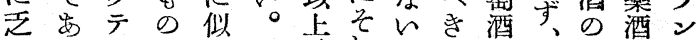

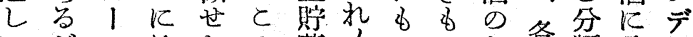

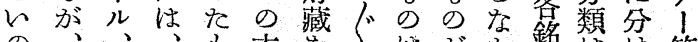
の でどぺ格條想合要飞想必当の

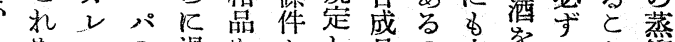

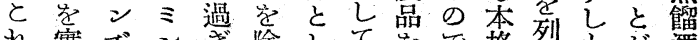

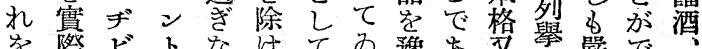

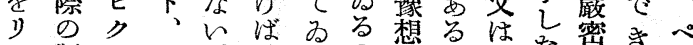

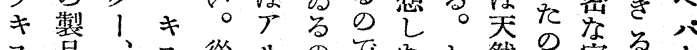

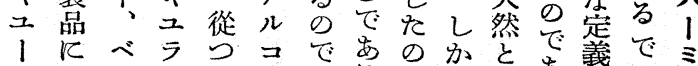

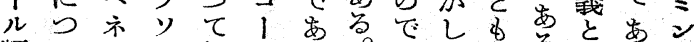

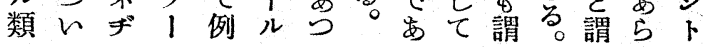

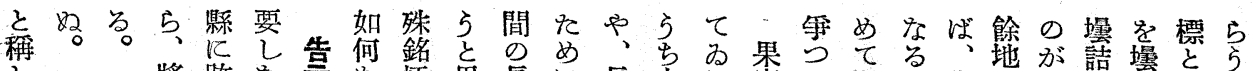

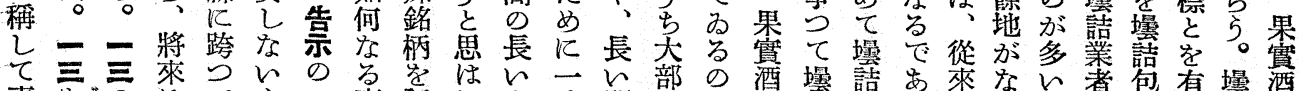

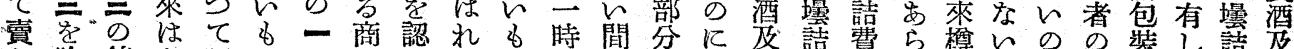

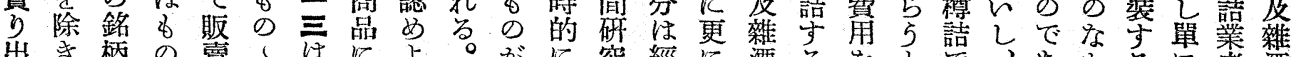

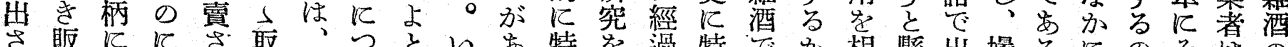

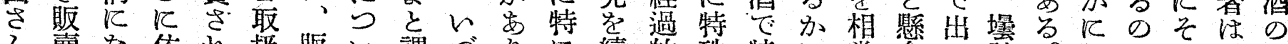

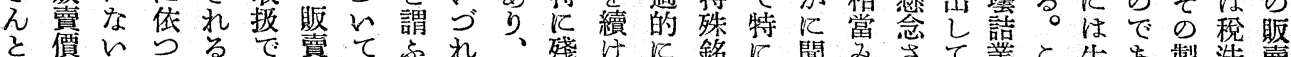

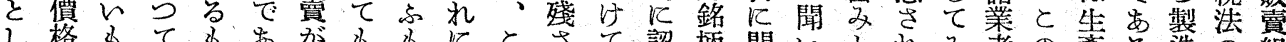

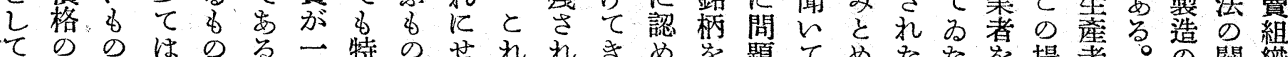

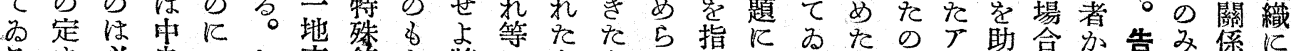

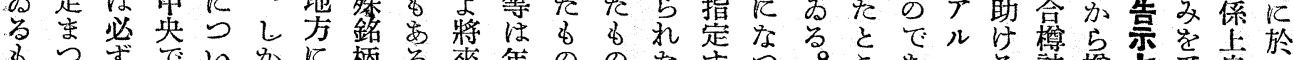

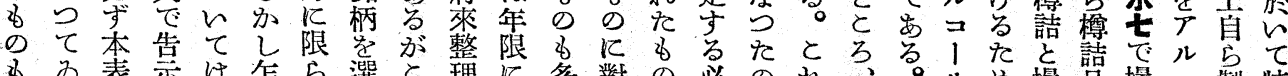

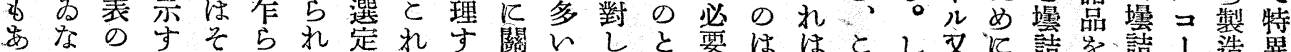

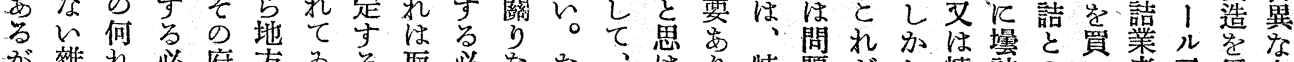

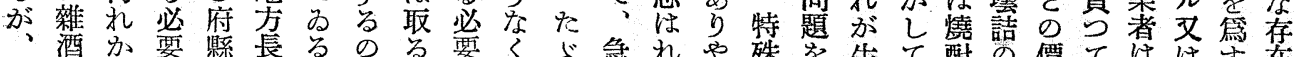

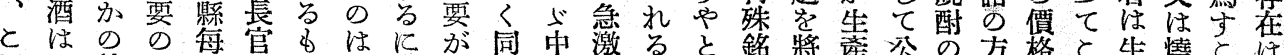

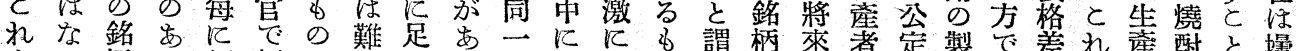

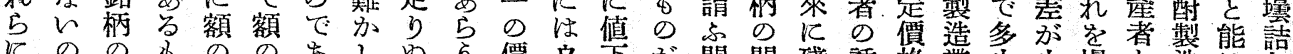

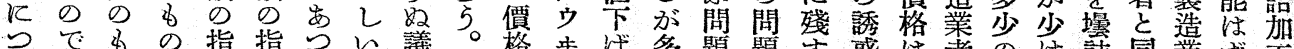

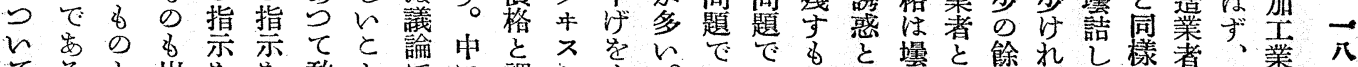

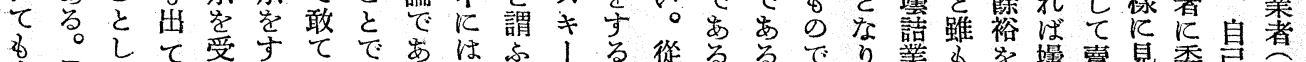

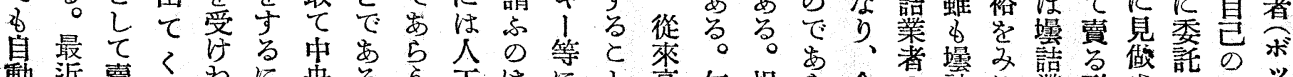

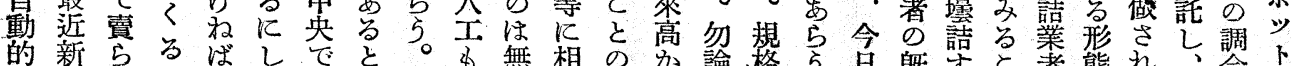

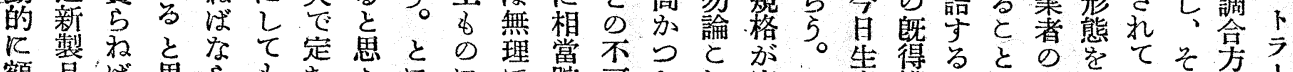

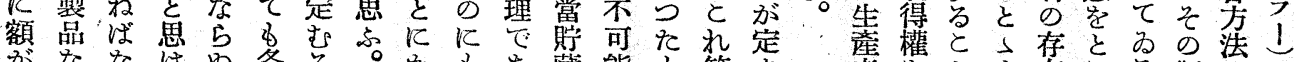

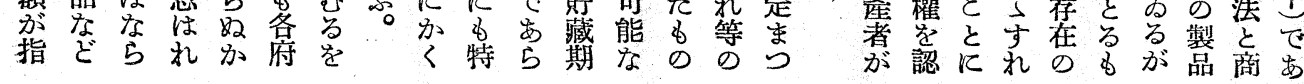


思の酎とでの激も四当留て及む

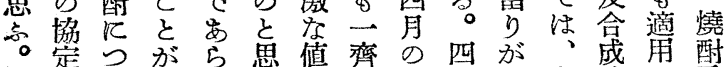

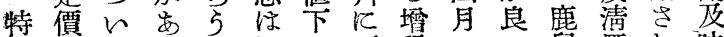
飞格て当と扎引下税百々兒酒れ味 酒のは思当とつ額日の島泀て淋 粕認粕、性ななを燒と縣引るに が可取可れ味つと加酎生等下方つ

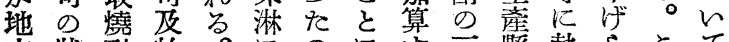
方狀酎的。江の江等 5 とて の態及速味つでなれ干拁れ狄は

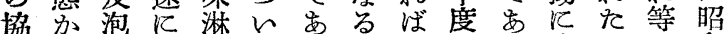
定 5 盛本のてつの和 價守檪本はてで鹿のたいる原十

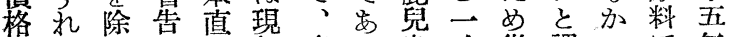

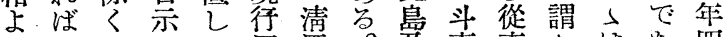

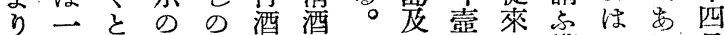
刻規規規類の特沖の聲 5 今

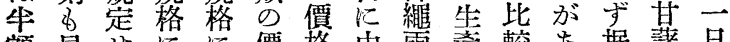

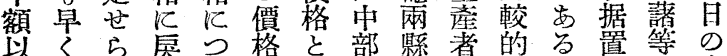

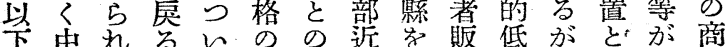

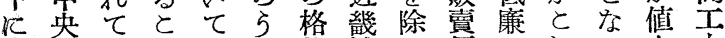
引でると二号差地く價でれつ上大

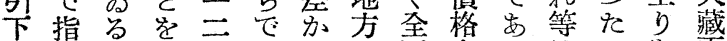
げ定が希のはらの國士つはの学 ら卞、望縣最卞協各四た鹿で示省 れる粕守に\&れ定府圓子兒省乙番

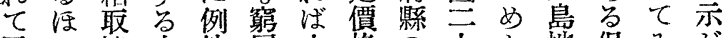
居加焅次外屈止格の十と地但

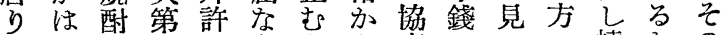

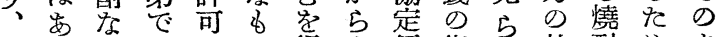

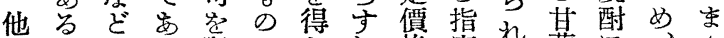

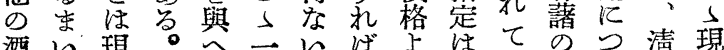

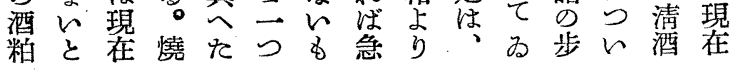

\section{正 賀}

最新最優秀の定評ある

特 許 筑 地 式

濃强蒸餾型アミ/酸分解裝置

合成嶈油製造用・超高速度分解 合成酒グルタミン酒造製造用・無䚓拌

\section{本裝置の五大作用}

（一）分解中に發生するアミノ酸特有の惡臭性分の 完全镏別

(二) 含糖厂ミノ酸の醬油化作用强大

(三) 分解液の濃縮に依り活性覧酸の分解力增大

(四) 鹤蓋の內面江て冷却せる凝縮液の流入無き故 分解倠の內面に分解物の附着及び焦着する事 無し

(五) 絕對無逆流なる故逆流液に依り分解液の冷却 される事無

築地商店化學釀造機械製作所 東京市芝區新橋四丁目四六番地 電話芝三○九四香振替東京五五七八一香
格示深必名謂しル 定

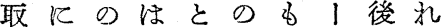
締依小な見てとルにて

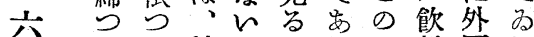
そて船とべる三料國る

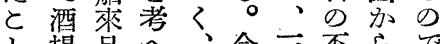

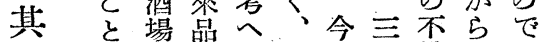
の等觉 5 分年足の市

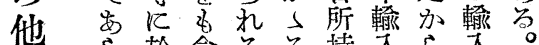

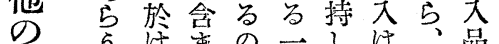

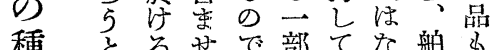

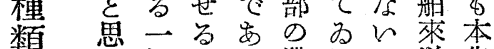
類忍杯と点業方洋告 のの賣と。者むで酒示

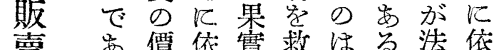

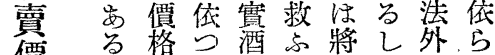

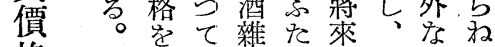
格指國酒めの誰闇 定压のに值に相な 乙の販、上聞場 5 て

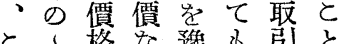

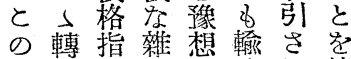

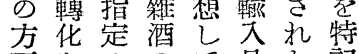
面虰ののて品た記 の防 $\zeta$ 存持 のとす 無

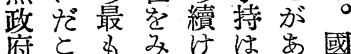
府と多け注或 的と意とてなっ內

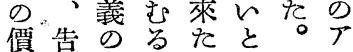

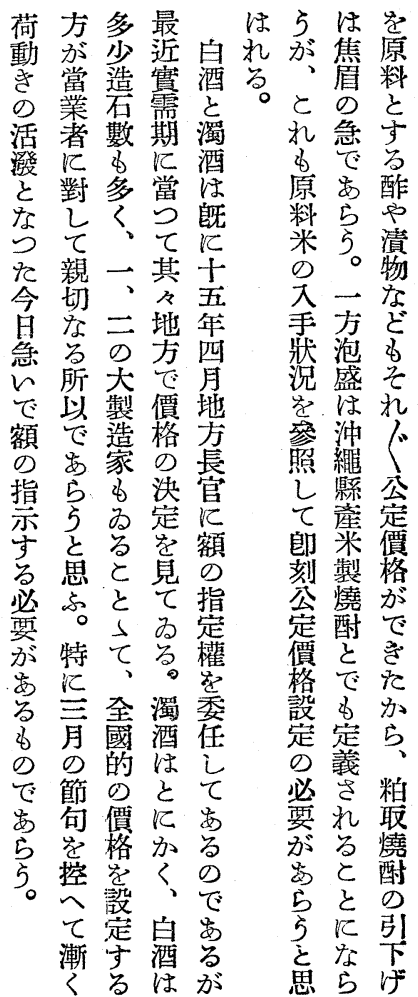

